\title{
Square of leaf area and photosynthetic potential of plants of pease depending on fertilizer and inoculation of seeds
}

\author{
V. Pylypenko, \\ postgraduate * \\ S. Kalenska, \\ Doctor of Agricultural Sciences, professor \\ National University of Life and Environmental sciences of Ukraine
}

The purpose. To determine features of formation of the square of leaf area and photosynthetic potential of pease of moustached morphotype in Forest-steppe region of Ukraine depending on fertilizer and inoculation of seeds. Methods. Field, laboratory, calculation-mathematical. Cultivars of domestic selection Tsarevitch and Deviz, biological preparation Rizohumin were used. Square of leaves was determined by the method of scanning the surface by means of computer program IpSquare. Results. Square of leaf area dynamically varied and depended on weather environment, nutrition background and inoculation of seeds. Application of phosphorus in top-dressing optimized assimilation of nitrogen. Inoculation of seeds promoted heightening of efficiency of nutrients of artificial fertilizers which were added both to base and foliar fertilizers. Conclusions. Greater square of leaf area and photosynthetic potential was gained at cultivar Tsarevitch. The greatest content of chlorophyll pigment and square of leaves of pease were gained at application N30P60K60 under basic soil cultivation and N30P30 in top-dressing (during vegetation) with simultaneous inoculation.

Key words: cultivar, pease, mineral fertilizers, leaf area, fertilizers, inoculation of seeds.

An important condition for formation of high yields of crops is increasing of photosynthesis productivity. Crops can realize this productivity potential through high intensity of photosynthesis, what is providing by optimum formation of leaf surface, which is able to function for a long time and also generate appropriate photosynthetic capacity and ensure steady accumulation of dry matter.

Among the biological characteristics of crops, including peas, crucial for their yield and protein potential are performance of photosynthesis [7]. From activity of photosynthesis, rate of leaf surface increasing and breath depend optimal plant growth and development that contribute accumulation of organic matter and level of yield structure features $[4,6]$.

Photosynthesis - the only one process in biosphere, which leads to the assimilation of solar energy and ensures existence of plants and all heterotrophic organisms. It also provides by energy all processes of growth and metabolism in the plant. For optimum passage of photosynthesis seeds must have a certain leaf surface area, heat and water balance in the entire biosphere. Well known that leaves is the main organ of photosynthesis, although part of this role takes also green stems, buds at early phase of their formation and even roots [2, 3].

In general, well known, that level of photosynthetic processes depends from species and varietal characteristics of the culture, soil and climatic conditions and availability of nutrients. Formation of the photosynthetic apparatus and intensity of gas exchange in the plants depends from provision by mineral nitrogen. Application of optimal doses nitrogen and phosphorus promotes growing of photosynthesis rate [5, 8, 9]. Established that due to different agricultural practices, fertilizers, foliar feeding, seed inoculation is possible to manage by formation and increasing of surface area of leafless peas.

Therefore, to maximize grain yield of peas, should be created optimal size of leaf surface and ensured better performance of each unit of the leaf surface of sowing, what will increase the photosynthetic productivity. So learning effect from doses of mineral nutrition and inoculation of seeds on leaf surface 
formation and photosynthetic capacity of peas at Forest-steppe of Ukraine is an important issue that requires further research and study.

The aim of study. One of the areas of our research is to determine the features of leaf surface formation and photosynthetic capacity of peas with leafless morphotype at the Forest-steppe of Ukraine depending of fertilization and seed inoculation.

Materials and methods of experiment. Research was conducted in 2014-2016's on stationary field experiment of Plant growing department NULES of Ukraine PC "Agronomic Research Station" (v. Psenychne, Vasylkiv district, Kyiv region). To achieve this goal was laid three-factor field experiment (table. 1).

Table 1. Scheme of field experiment

\begin{tabular}{|c|c|c|c|c|c|c|}
\hline \multirow{2}{*}{$\begin{array}{l}\text { Factor V: } \\
\text { Variety }\end{array}$} & \multicolumn{5}{|c|}{ Factor F: System of fertilizing } & \multirow{2}{*}{$\begin{array}{l}\text { Factor I: } \\
\text { Seeds inoculation }\end{array}$} \\
\hline & Variant & Base fertilizer & $\begin{array}{l}\text { BBCH } \\
13-19\end{array}$ & $\begin{array}{l}\text { BBCH } \\
55-59\end{array}$ & $\begin{array}{l}\mathrm{BBCH} \\
61-65\end{array}$ & \\
\hline $\mathrm{V}_{1}-$ Deviz & $F_{1}$ & $\begin{array}{l}\text { Control (without } \\
\text { fertilizers - C) }\end{array}$ & - & - & - & $\begin{array}{ll}- & \text { without } \\
\text { inoculation } & \end{array}$ \\
\hline $\mathrm{V}_{2}-$ Tsarevych & $\begin{array}{l}F_{i} \\
F_{i} \\
F_{i} \\
F_{i} \\
F_{i} \\
F_{1} \\
F_{l} \\
F_{9} \\
F_{10} \\
F_{11} \\
F_{12}\end{array}$ & $\begin{array}{l}\mathrm{N}_{30} \mathrm{P}_{60} \mathrm{~K}_{60}\left(\mathrm{C}_{2}\right) \\
\mathrm{N}_{60} \mathrm{P}_{60} \mathrm{~K}_{60} \\
\mathrm{~N}_{30} \mathrm{P}_{90} \mathrm{~K}_{60} \\
\mathrm{~N}_{90} \mathrm{P}_{90} \mathrm{~K}_{60} \\
\mathrm{~N}_{30} \mathrm{P}_{90} \mathrm{~K}_{90} \\
\mathrm{C} \\
\mathrm{C} \\
\mathrm{C} \\
\mathrm{C}_{2} \\
\mathrm{C}_{2} \\
\mathrm{C}_{2}\end{array}$ & $\begin{array}{l}- \\
- \\
- \\
\mathrm{N}_{10} \\
\mathrm{P}_{10} \\
\mathrm{~N}_{10} \mathrm{P}_{10} \\
\mathrm{~N}_{10} \\
\mathrm{P}_{10} \\
\mathrm{~N}_{10} \mathrm{P}_{10}\end{array}$ & $\begin{array}{l}- \\
- \\
- \\
- \\
- \\
\mathrm{N}_{10} \\
\mathrm{P}_{10} \\
\mathrm{~N}_{10} \mathrm{P}_{10} \\
\mathrm{~N}_{10} \\
\mathrm{P}_{10} \\
\mathrm{~N}_{10} \mathrm{P}_{10}\end{array}$ & $\begin{array}{l}- \\
- \\
- \\
- \\
- \\
\mathrm{N}_{10} \\
\mathrm{P}_{10} \\
\mathrm{~N}_{10} \mathrm{P}_{10} \\
\mathrm{~N}_{10} \\
\mathrm{P}_{10} \\
\mathrm{~N}_{10} \mathrm{P}_{10}\end{array}$ & $l_{2}-$ with inoculation \\
\hline
\end{tabular}

Soil of the research area - a typical black low-humus soil, by particle size - medium loamy, by humus content at arable layer of soil $4,53-4,38 \%$, pH of salt extract $6,8-7,3$. Square of elementary area $-30 \mathrm{~m}^{2}$, of counted $-25 \mathrm{~m}$. Quadruple repetition of the experiment, the systematic placement options [3].

Main fertilizing was applied under presowing cultivation. Seeding rate $-1,2$ million seeds per 1 ha. At the day of planting was carried bacterization by suspension biopreparation Ryzohumin. Predecessor of peas in crop rotation is winter rape.

During the growing season on field experiment was selected samples of pea plants by stages of growth and development: BBCH 13-19 (3 leaves or antennae (with stipules), developed) BBCH 55-59 (first separated flower buds visible behind the leaves, but flowers are still closed) BBCH 69-71 (full flowering: $50 \%$ flowers open - fetal development ( $10 \%$ of pods have reached to normal length) [10], from which was determined leaves area by contour method with scanning of the surface and area calculation with using a computer program IpSquare [1].

At the study were used varieties of domestic breeding - Tsarevych and Deviz (V. Y. Yuriev). Sowing was carried when soil temperature at a depth of seeds earning was $3-5^{\circ} \mathrm{C}$ by seeding machine "Great Plains" with row spacing $-18 \mathrm{~cm}$ on a depth $4-6 \mathrm{~cm}$. Laboratory studies was conducted in educational and scientific laboratory "Analytical study in Plant growing" of Plant growing department National University of Life and Environmental sciences of Ukraine.

Results of research. During our research was found that leaf surface area dynamically varied and depended from fertilizer, seed inoculation and weather. Hydrothermal conditions of the studied years were mixed, what is allowed us to fully determine the efficacy of the studied factors.

Content of chlorophyll in the leaves and stipules of pea plants varied significantly and depend from fertilizing system of plants, which cause intensification of photosynthesis and changing of plant parameters, including the size of leaf surface (Table. 2). Using of fertilizers with different fertilization systems has 
increased amount of chlorophyll content compare with a control variant, where fertilizers weren't applied at all microstages of plants.

Phosphorus used in extra feeding helps to intensify photosynthesis process, what is displayed in increasing of chlorophyll content amount in the leaves and stipules of pea plants.

Also using of phosphorus in extra feeding optimize nitrogen fixation and increase efficiency of urea, used for foliar application. This is especially evident at the early microstages of development (BBCH 13-19) chlorophyll content was 55,4 and 51,0 for seeds without inoculation and 60,8 and $62,4 \mathrm{mg} / \mathrm{g}$ of wet substance for inoculated seeds for varieties Tsarevych and Deviz respectively.

Inoculation of seeds contributed to improving efficiency of nutrients from mineral fertilizers, which were introduced as a basic fertilization and as foliar application.

Using of different doses of fertilizers boosted chloroplasts content starting from stage 13-19 BBCH, as in the leaves and in mustaches of plants also. Was established a positive reaction of peas varieties Deviz and Tsarevych on accumulation of chlorophyll not only on low nitrogen backgrounds, and on the backgrounds with high content. Optimal plant growth and development were received on variant $F_{\ell}$, where was applied $\mathrm{N}_{\sharp} \mathrm{P}_{\|} \mathrm{K}_{\|}$with main tillage and in extra feeding $\mathrm{N}_{\sharp} \mathrm{P}_{\|}$with simultaneous inoculation.

Table 2. Content of chlorophyll (the sum of $a$ and $b$ ) in the leaves and stipules of leafless peas, $\mathrm{mg} / \mathrm{g}$ wet weight of leaf surface (average for 2014-2016).

\begin{tabular}{|c|c|c|c|c|c|c|c|c|c|c|c|c|}
\hline \multirow{5}{*}{$\frac{\text { D }}{\frac{\stackrel{D}{N}}{\underline{\underline{T}}}}$} & \multicolumn{6}{|c|}{ Tsarevych } & \multicolumn{6}{|l|}{ Deviz } \\
\hline & \multicolumn{12}{|c|}{ Stages of plant growth and development } \\
\hline & \multicolumn{2}{|c|}{$\begin{array}{l}\mathrm{BBCH} \\
13-19\end{array}$} & \multicolumn{2}{|c|}{$\begin{array}{l}\mathrm{BBCH} \\
55-59\end{array}$} & \multicolumn{2}{|c|}{$\begin{array}{l}\mathrm{BBCH} \\
69-71\end{array}$} & \multicolumn{2}{|c|}{$\begin{array}{l}\mathrm{BBCH} \\
13-19\end{array}$} & \multicolumn{2}{|c|}{$\begin{array}{l}\mathrm{BBCH} \\
55-59\end{array}$} & \multicolumn{2}{|c|}{$\begin{array}{l}\mathrm{BBCH} \\
69-71\end{array}$} \\
\hline & \multicolumn{12}{|c|}{ Presowing seed treatment by ryzohumin } \\
\hline & $w / i^{i}$ & $\mathrm{i}^{2}$ & $\mathrm{w} / \mathrm{i}$ & $\mathrm{i}$ & $\mathrm{w} / \mathrm{i}$ & $\mathrm{i}$ & $\mathrm{w} / \mathrm{i}$ & $\mathrm{i}$ & $\mathrm{w} / \mathrm{i}$ & $\mathrm{i}$ & $\mathrm{w} / \mathrm{i}$ & $\mathrm{i}$ \\
\hline$\frac{L}{F}$ & 22,8 & 24,0 & 16,7 & 19,6 & 16,7 & 19,6 & 22,1 & 24,8 & 18,9 & 21,5 & 18,9 & 19,4 \\
\hline$F_{2}$ & 28,3 & 30,2 & 24,5 & 28,2 & 21,7 & 25,4 & 31,1 & 35,4 & 27,4 & 31,4 & 23,5 & 27,2 \\
\hline $\mathrm{F}_{3}$ & 27,2 & 28,0 & 24,3 & 24,6 & 21,1 & 21,3 & 26,1 & 28,4 & 25,3 & 26,9 & 20,8 & 19,6 \\
\hline$F_{4}$ & 23,5 & 25,1 & 19,2 & 21,2 & 18,5 & 19,8 & 17,8 & 20,1 & 14,0 & 17,2 & 14,0 & 17,2 \\
\hline $\mathrm{F}_{i}$ & 30,7 & 32,5 & 26,1 & 28,8 & 23,8 & 24,7 & 24,4 & 26,8 & 13,3 & 21,4 & 15,4 & 16,0 \\
\hline $\mathrm{F}_{i}$ & 36,3 & 38,5 & 30,5 & 31,6 & 26,9 & 27,4 & 28,4 & 29,6 & 31,8 & 32,4 & 26,0 & 28,3 \\
\hline$F_{1}$ & 33,3 & 34,9 & 28,1 & 28,8 & 22,2 & 23,3 & 30,4 & 32,7 & 27,6 & 38,5 & 21,1 & 22,7 \\
\hline$F_{0}$ & 30,6 & 31,5 & 27,4 & 29,1 & 24,9 & 26,0 & 31,4 & 33,8 & 28,5 & 29,0 & 23,5 & 23,9 \\
\hline$F_{i}$ & 34,2 & 35,6 & 30,4 & 30,8 & 26,1 & 26,9 & 34,7 & 35,9 & 31,5 & 32,1 & 26,8 & 27,0 \\
\hline$F_{10}$ & 36,8 & 38,3 & 31,6 & 32,9 & 26,8 & 27,2 & 35,2 & 37,9 & 31,9 & 32,6 & 26,0 & 26,9 \\
\hline$F_{11}$ & 37,9 & 39,0 & 33,3 & 33,9 & 27,4 & 27,5 & 37,7 & 40,7 & 32,8 & 34,5 & 27,2 & 29,0 \\
\hline$F_{12}$ & 55,4 & 60,8 & 35,8 & 35,9 & 27,5 & 27,9 & 51,0 & 62,4 & 33,3 & 35,4 & 27,8 & 29,3 \\
\hline \multicolumn{9}{|c|}{$L S D_{\text {\& }}$ for factor «fertilizing» } & \multicolumn{4}{|l|}{$\begin{array}{l}4,8 \\
2.9\end{array}$} \\
\hline
\end{tabular}

Remarks *:-without inoculation; ${ }^{2}$ - inoculated seed.

Leaf surface area of the studied variants depended from varietal characteristics of plants, weather conditions, fertilization and inoculation. From stage $\mathrm{BBCH}$ 13-19 to stage $\mathrm{BBCH}$ 69-71 was observed growth of leaf surface leafless peas. On the next stages of peas development was noted decreasing of the leaf area, the reason of it - aging and dying leaves at the lower tiers of plant. 
Table 3. Growth dynamics of leaf surface area leafless peas depending of fertilization and seed inoculation, cm/plant (average 2014 -2016 years.)

\begin{tabular}{|c|c|c|c|c|c|c|c|}
\hline \multirow[t]{4}{*}{ Variety } & \multirow[t]{4}{*}{ Fertilizing } & \multicolumn{6}{|c|}{ Stages of plant growth and development } \\
\hline & & \multicolumn{2}{|c|}{$\begin{array}{l}\mathrm{BBCH} \\
13-19\end{array}$} & \multicolumn{2}{|c|}{$\begin{array}{l}\text { BBCH } \\
55-59\end{array}$} & \multicolumn{2}{|c|}{$\begin{array}{l}\mathrm{BBCH} \\
69-71\end{array}$} \\
\hline & & \multicolumn{6}{|c|}{ Presowing seed treatment by ryzohumin } \\
\hline & & w/i' & $\mathbf{i}^{2}$ & $w / i$ & $\mathbf{i}$ & w/i & $\mathbf{i}$ \\
\hline \multirow{12}{*}{ Tsarevych } & $F_{1}$ & 19,1 & 19,6 & 260,5 & 272,4 & 420,3 & 421,7 \\
\hline & $\mathrm{F}_{l}$ & 24,1 & 25,2 & 281,6 & 288,9 & 455,6 & 460,2 \\
\hline & $F_{3}$ & 26,0 & 26,7 & 302,8 & 310,3 & 477,5 & 481,1 \\
\hline & $F_{4}$ & 32,0 & 33,1 & 322,2 & 334,2 & 489,9 & 493,2 \\
\hline & $F_{5}$ & 36,8 & 37,5 & 342,4 & 350,1 & 515,3 & 520,6 \\
\hline & $F_{6}$ & 39,2 & 41,4 & 357,2 & 360,6 & 536,7 & 540,2 \\
\hline & $F_{1}$ & 19,7 & 21,9 & 268,9 & 275,4 & 427,7 & 430,1 \\
\hline & $F_{8}$ & 20,2 & 22,3 & 292,2 & 301,1 & 462,3 & 465,0 \\
\hline & $F_{1}$ & 23,3 & 23,7 & 289,3 & 326,2 & 477,1 & 483,5 \\
\hline & $F_{10}$ & 27,1 & 27,3 & 305,3 & 312,3 & 483,2 & 485,1 \\
\hline & $F_{11}$ & 32,8 & 33,9 & 324,6 & 330,1 & 490,3 & 497,8 \\
\hline & $F_{12}$ & 37,4 & 39,5 & 358,5 & 361,3 & 548,9 & 555,5 \\
\hline \multirow{12}{*}{ Deviz } & $F$ & 18,8 & 19,7 & 257,8 & 268,3 & 419,3 & 426,4 \\
\hline & $F_{2}$ & 23,9 & 24,4 & 277,4 & 286,6 & 451,3 & 456,5 \\
\hline & $F_{3}$ & 25,5 & 26,9 & 300,6 & 305,9 & 471,0 & 479,4 \\
\hline & $F_{1}$ & 30,2 & 31,9 & 318,8 & 329,9 & 485,3 & 490.0 \\
\hline & $F_{i}$ & 38,4 & 40,7 & 341,8 & 348,4 & 509,5 & 514,2 \\
\hline & $F_{i}$ & 39,1 & 41,0 & 350,3 & 359,8 & 540,5 & 541,1 \\
\hline & $F_{l}$ & 19,6 & 20,6 & 277,6 & 289,7 & 421,2 & 429,8 \\
\hline & $F_{i}$ & 21,0 & 21,9 & 287,3 & 291,5 & 464,4 & 469,5 \\
\hline & $F_{\ell}$ & 22,9 & 23,2 & 284,2 & 310,9 & 479,9 & 481,5 \\
\hline & $F_{10}$ & 27,5 & 27,7 & 311,5 & 310,2 & 481,6 & 489,7 \\
\hline & $F_{11}$ & 33,7 & 34,4 & 328,2 & 332,2 & 492,4 & 497,1 \\
\hline & $F_{12}$ & 37,9 & 39,9 & 348,4 & 359,8 & 543,5 & 552,1 \\
\hline \multicolumn{6}{|c|}{ 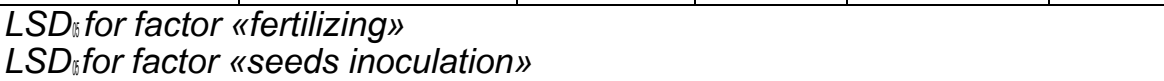 } & \multicolumn{2}{|c|}{$\begin{array}{l}25,4 \\
14,3\end{array}$} \\
\hline
\end{tabular}

At phase of three sheets plants at the variant $F$ formed leaves area $18,8 \mathrm{~cm}^{2} /$ plant at variety Deviz and $19,1 \mathrm{~cm}^{2} /$ plant at variety Tsarevych without inoculation. With making inoculation leaf area was increased on $0,5 \mathrm{~cm}^{2} /$ plant at variety Tsarevych and on $0,9 \mathrm{~cm}^{2} /$ plant at variety Deviz. The biggest leaf surface was obtained at the variant $F_{i}-39,1-39,2 \mathrm{~cm}^{2} /$ plant without inoculation and $\quad 41,0-41,4 \mathrm{~cm}^{2} /$ plant with inoculation. Carrying only extra feeding on peas seedings at dose $\mathrm{N}_{\sharp}$ not boosted the leaf surface area, as evidenced gotten numbers that are on the same level as control (without fertilizer).

On stage BBCH 55-59 (first separated flower buds visible behind the leaves, but flowers are still closed) leaf surface area was increased at control variant to $257,8-260,5 \mathrm{~cm} /$ plant without inoculation and to $268,3-272,4 \mathrm{~cm} /$ plant with inoculation. The biggest leaf surface was noted in variant $F_{1}-358,5 \mathrm{~cm}^{2} /$ plant without inoculation and $361.3 \mathrm{~cm} /$ plant with inoculation at variety Tsarevych. At variety Deviz biggest area of leaf surface was obtained in the variant $F_{6}-350,3 \mathrm{~cm}^{2} /$ plant without inoculation and $359,8 \mathrm{~cm}^{2} /$ plant with inoculation. Application in extra feeding with doses $N_{\sharp} P_{\Downarrow}$ (during vegetation) contributed to minor increasing of leaf surface area, as evidenced gotten numbers that are on the same level as variant $F_{1}$.

At the beginning of flowering (BBCH 69-71) leaf surface area was increased at 1,5-1,6 times compare with stage $\mathrm{BBCH} 55-59$ and in control variant was $419,3-420,3 \mathrm{~cm}^{2} /$ plant without inoculation and $421,7-426,4 \mathrm{~cm}^{2} /$ plant with inoculation.

The biggest leaf surface area at early flowering was formed by variant $F_{2}-543,5-548,9 \mathrm{~cm}^{2} /$ plant without inoculation and 552,1-555,5 $\mathrm{cm}^{2} /$ plant with inoculation. Adding $\mathrm{N}_{*}$ as extra feeding (during vegetation) contributed to minor increase of leaf that was on the same level as control (without fertilizer). 


\section{Conclusions}

After comparing two studied varieties clear that a larger area of leaf surface and photosynthetic capacity were received at variety Tsarevych.

The highest chlorophyll content and leaf area of leafless peas was obtained with application of fertilizers during primary tillage $N_{\mathbb{N}} P_{\mathbb{N}} K_{\mathbb{N}}$ and in extra nutrition $N_{\mathbb{N}} P_{\mathbb{N}}$ (during vegetation) with simultaneous inoculation.

\section{References}

1. Petrychenko V.F., Lisova T.Ye. Shlyakhy pidvyshchennya produktyvnosti horokhu $v$ umovakh Lisostepu Ukrayiny / V. F. Petrychenko // Zbirnyk naukovykh prats' Vinnyts'koho derzhavnoho ahrarnoho universytetu. - Vinnytsya, 2001. - Vyp. 9. - S. 74-77.

2. Kalenska S. M. Poverkhnevi lipidy ta stiikist roslyn zernobobovykh kultur do stresovykh chynnykiv $v$ umovakh Pravoberezhnoho Lisostepu Ukrainy IS. M. Kalenska, V. A. Nidzelskyi, V. S. Pylypenko, N. lu. Taran, V. O. Storozhenko // Naukovi dopovidi NUBiP Ukrainy, 2016. - 3(60).

3. . Petrychenko V. F., Antypin R. A. Fotosyntetychna produktyvnist horokhu zalezhno vid vplyvu tekhnolohichnykh pryiomiv vyroshchuvannia v umovakh Lisostepu Ukrainy / V. F Petrychenko., R. A. Antypin // Kormy i kormovyrobnytstvo. - Vinnytsia, 2006. - Vyp. 57. - S. 3 -14.

4. Garbar L. A. Vplyv elementiv tekhnolohii vyroshchuvannia na formuvannia asymiliatsiinoho aparatu posivamy vivsa / L.A. Garbar, R.M. Holodchenko, V.V. Shevchuk // Naukovyi visnyk Natsionalnoho universytetu bioresursiv i pryrodokorystuvannia Ukrainy. Seriia: Ahronomiia //. - 2013. — №. 183 (2). — s.79-82.

5. Doslidna sprava a ahronomii: navch. Posibnyk: u 2 kn. - Kn.1. Teoretychni aspekty doslidnoi spravy / A. O. Rozhkov, V. K. Puzik, S. M. Kalenska ta in.; za red. A. O. Rozhkova. - Kh.: Maidan, 2016. - 316 s.

6. Nidzelskyi V. A., Kovalenko V. P. Udoskonalennia metodiv vyznachennia ploshchi asymiliatsiinoi poverkhni horokhu vusatoho / V. A. Nidzelskyi, V. P. Kovalenko // Naukovyi visnyk Natsionalnoho universytetu bioresursiv i pryrodokorystuvannia Ukrainy. Ser.: Ahronomiia. - 2012. - №. 176. - S. 49-53. [Elektronnyi resurs] — Rezhym dostupu: http://journals.nubip.edu.ua/index.php/ Dopovidi/article/view /6827.

7. Clayton G.W., Rice W.A. Inoculant formulation and fertilizer nitrogen effects of field pea: crop yield and seed quality // Clayton G.W., Rice W.A., Lupwayi N.Z and other // Canadian Journal of Plant Science. 2004. - 84(1). - P. $89-96$.

8. Stauss R. Einheitliche Codierung derphänologischen Entwicklungsstadien mono- und dikotyler Pflanzen. Erweiterte BBCH-Skala: Allgemein / R. Stauss., H. Bleiholder, T. Van Den Boom and other // CibaGeigy AG, Basel, 1994. - 58 s.

9. Fernandes M. S., Pereyra Rossiello R. O. Mineral nitrogen in plant physiology and plant nutrition / M.S. Fernandes, R. O. Pereyra Rossiello // Critical reviews in plant sciences, (1995). - 14(2). - P. 11-148.

10. Vychyslenye ploshchady fihur proyzvol'noy formy [Elektronnyy resurs] - Rezhym dostupu:IpSquare //http://lprosoft.at.ua/load/1-1-0-4. 